\title{
Sintered Hydroxyapatite Ceramic for Wear Studies
}

\author{
Hiujar M. Rootarf, John M. Powfrs, and Robert G. Craig \\ School of Dentistry, The University of Michigan, Ann Arbor Michigan 48109, USA
}

A sintered hydroxyapatite (HAP) ceramic for use in wear studies was prepared from a commerical tricalcium phosphate. The sintered HAP had physical properties close to those of human enamel. The coefficient of friction and wear of the sintered HAP ceramic as characterized by tangential force, track width, and surface failure data, approximated those of human enamel.

\section{J Dent Res 57(7-8):777-783, July-August 1978.}

Hydroxyapatite (HAP) is the major mineral component of hard tissues of bone and dental enamel. Because of the biological compatibility of HAP with these tissues, ${ }^{1}$ various studies of preparation, compaction and sintering of HAP have been reported in the literature. ${ }^{2-\tau}$ These efforts have been directed toward development of a strong polycrystalline ceramic implant material from pure hydroxyapatite. Uniaxial compaction of the powdered HAP has also been investigated $\mathrm{d}^{4,7,8}$ as well as the conversion of the compact to a HAP ceramic by sintering at $1200 \mathrm{C}$ in an atmosphere of nitrogen and steam. ${ }^{8}$ The resulting densification and porosity changes have been determined by high pressure mercury porosimetry. ${ }^{8-10}$

The objectives of this investigation were: (1) to prepare compacts from tricalcium phosphate powder of various bulk densities by isostatic compaction, (2) to sinter these compacts at temperatures up to $1,200 \mathrm{C}$ in an atmosphere with a high partial pressure of water vapor to

Received for publication December 9, 1977.

Accepted for publication January 10, 1978 .

This investigation was presented at the annual meeting of the American Association for Dental Research, Las Vegas, Nevada, June 19, 1977.

This investigation was supported by USPHS Research Grant DE-03416 from the National Institute of Dental Research, National Institutes of Health, Bethesda, Maryland 20014. 63166.

* Monsanto Co., Inorganic Chemicals, St. Louis, Mo

Model 5-7125B, American Instrument Co., Silver Spring, Md 20910.

\$ Model 54253, Lindberg Hevi-Duty, Sola Basic Industries, Watertown, Wi 53094. effect the conversion into crystalline HAP, (3) to determine physical properties of the sintered compacts and to compare them with those of dental enamel, and (4) to characterize the wear of the HAP ceramic by a single-pass sliding technique and to compare its frictional behavior and surface failure with human enamel to determine if the HAP ceramic might serve as a model for wear studies of human enamel.

\section{Materials and Methods}

The hydroxyapatite sample was a commercial product* labeled tricalcium phosphate with a surface area of $60.5 \mathrm{~m}^{2} / \mathrm{gm}$. Approximately $5 \mathrm{gm}$ samples of the powder were compacted in a cylindrical rubber mold $(5 \mathrm{~cm}$ deep and $1.3 \mathrm{~cm}$ in diameter) using a mercury porosimeter $\dagger$ as an isostatic press. The powders were compressed at $69,138,276$, and $414 \mathrm{MPa}$ with a constant pressure maintained for about 20 minutes. Values of pore volume, pore size distribution, and density of the compacts were determined by mercury porosimetry.

Sintering of the HAP compacts was conducted in a single-zone, high temperature furnace. + The atmosphere in the furnace was controlled by the flow of one liter/minute of equal volumes of nitrogen and steam. ${ }^{8}$ Steam was obtained by bubbling nitrogen gas through a heated flask of distilled water held at approximately 85 to $90 \mathrm{C}$, and then blown into the furnace tube. The sintering procedure used was analogous to that of the preparation by solid state reaction of TVA hydroxyapatite from a stoichiometric mixture of $\mathrm{Ca}\left(\mathrm{H}_{2} \mathrm{PO}_{4}\right)_{2} \cdot \mathrm{H}_{2} \mathrm{O}$ and $\mathrm{CaCO}_{3}, "$ "Sintering was conducted at temperatures of 1100 and $1200 \mathrm{C}$ for up to 12 hours. The average weight loss of a compact made at $414 \mathrm{MPa}(60,000 \mathrm{psi})$ and sintered at $1200 \mathrm{C}$ for 12 hours (HAP-60K-1200C) was $5.68(0.03) \%$ and was attributed to loss of adsorbed water and included carbonate. The linear and volumetric dimensional changes were $15.8(0.2) \%$ and $40.3(0.1) \%$ for the same sintered compacts. 
The specimens for physical testing were prepared on a lathe by cutting compacted but not sintered (green) samples into right cylinders of approximately $8 \times 16 \mathrm{~mm}$ which on sintering reduced to specimens about $7 \times 14 \mathrm{~mm}$. Young's modulus and the ultimate compressive strength were measured on a testing machine ness $\dagger$ was measured on specimens embedded in plastic and polished to a fine polish with $0.05-$ $\mu \mathrm{m}$ levigated alumina. The lincar coefficients of thermal expansion were measured on a thermomechanical analyzerti in the range of -50 to $90 \mathrm{C}$. The temperatures below ambient were obtained by cooling with liquid nitrogen.

Tangential force and track widths were used to characterize wear of the sintered specimens in distilled water by single-pass sliding of a diamond stylus under normal loads varying from 1 to $10 \mathrm{~N}$. The apparatus and the method used for scratching the surface have been described previously. ${ }^{11}$ The track width was determined under optical magnification $(500 \times) . \S$ A scanning electron microscope (SEM) \# was used to obtain photomicrographs of the tracks and also of the crystal structure of the surface. The measured values of the track widths were compared with values computed from Hertz's equation based on a theory of contact between two elastic spheres. ${ }^{12,13}$

\section{Results}

The sintered compacts showed no open porosity, whereas the porosity of the green compacts was reduced from $0.376 \mathrm{~cm}^{3} / \mathrm{gm}$ at $69 \mathrm{MPa}$ to $0.218 \mathrm{~cm}^{3} / \mathrm{gm}$ at $414 \mathrm{MPa}$ or a $42 \%$ reduction in pore volume and was accompanied by a $50 \%$ reduction in the median pore diameter. The change in pore volume above 276 MPA was caused mostly by a reduction in volume of the larger voids, and it amounted to only $3.8 \%$ of the total volume change between 69 and $414 \mathrm{MPa}$.

Changes in bulk density with compaction pressure, sintering temperature, and time are shown in Figure 1. The bulk density of the § Ametek, Inc. Riehle Testing Machines, E. Moline,
Illinois.

using an optical strain gauge.* Knoop hard* Tuckerman, American Instrument Co., Silver Spring, Md 20910.

06602 Wilson Instrument Div, ACCO, Bridgeport, $\mathrm{Ct}$

ț Model 941, E. I. duPont de Nemours \& Co., Inc., Instrument Products Division, Wilmington, De 19898.

\$ Aristophot, Ernst Leitz, Wetzlar, W Germany.

\# SMS-11, International Scientific Instruments, Mountain View, Ca.

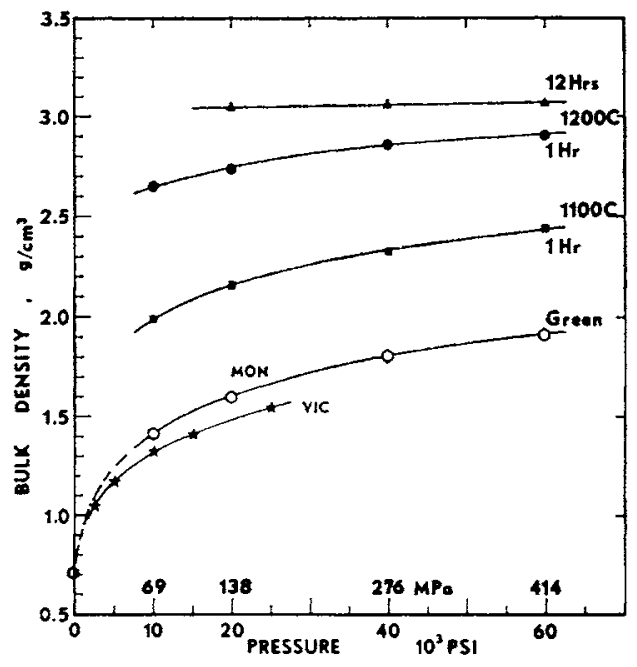

Fig 1.-Bulk densities of green compacts made from Monsanto (MON) and Victor Chemical Company (VIC) powders. The sintered HAP ceramics were made from MON powder.

powder $\left(0.7 \mathrm{gm} / \mathrm{cm}^{3}\right)$ was doubled to 1.42 (0.01) $\mathrm{gm} / \mathrm{cm}^{3}$ by compaction of $69 \mathrm{MPa}$. The green compacts were densified further to 1.98 (0.01) $\mathrm{gm} / \mathrm{cm}^{3}$ by increasing the pressure to $414 \mathrm{MPa}$. Sintering at $1100 \mathrm{C}$ for 1 hour caused a $30 \%$ increase in the bulk density. $A$ similar increase was again observed by sintering for 1 hour at $1200 \mathrm{G}$, however, the maximum observed bulk densities of $3.10 \mathrm{gm} / \mathrm{cm}^{3}$ were reached at $1,200 \mathrm{C}$ for periods of 3 hours or longer.

SEM photomicrographs of the crystal structure of the sintered HAP specimens are shown in Figure 2. In order to develop the detail of the grain structure, the polished surface was etched with $50 \%$ phosphoric acid for 30 seconds and then gold-coated by vapor deposition. The 3 photomicrographs $A, B$, and $G$ show the surfaces of the specimens compacted at 138,276 , and $414 \mathrm{MPa}$, respectively, after sintering for 12 hours. At $1,000 \times$ magnification the dense ceramic was observed to have some closed porosity. A $5,000 \times$ photomicrograph (D) showed more detailed grain structure of the HAP-60K-1200C specimen. Even though the density of the specimens was between 97 and $98 \%$ of the theoretical value, there were closed pores, as shown in these micrographs, that accounted for the missing 2 or $3 \%$. This closed porosity is the limiting factor in obtaining $100 \%$ densification by sintering at $1200 \mathrm{C}$. 
Physical properties of the HAP-60K1200C sintered compacts are compared with those of enamel ${ }^{1+-16}$ in the Table. The compressive strength, Young's modulus, density, coefficient of friction, and linear coefficient of thermal expansion of the sintered HAP ceramic all compared closely with those of dental enamel. The Knoop hardness number $(450 \mathrm{~kg}$ / $\left.\mathrm{mm}^{2}\right)$, however, was higher than that of enamel $\left(343 \mathrm{~kg} / \mathrm{mm}^{2}\right)$.

Knoop hardness of the sintered HAP surfaces was observed to be load dependent. Loads

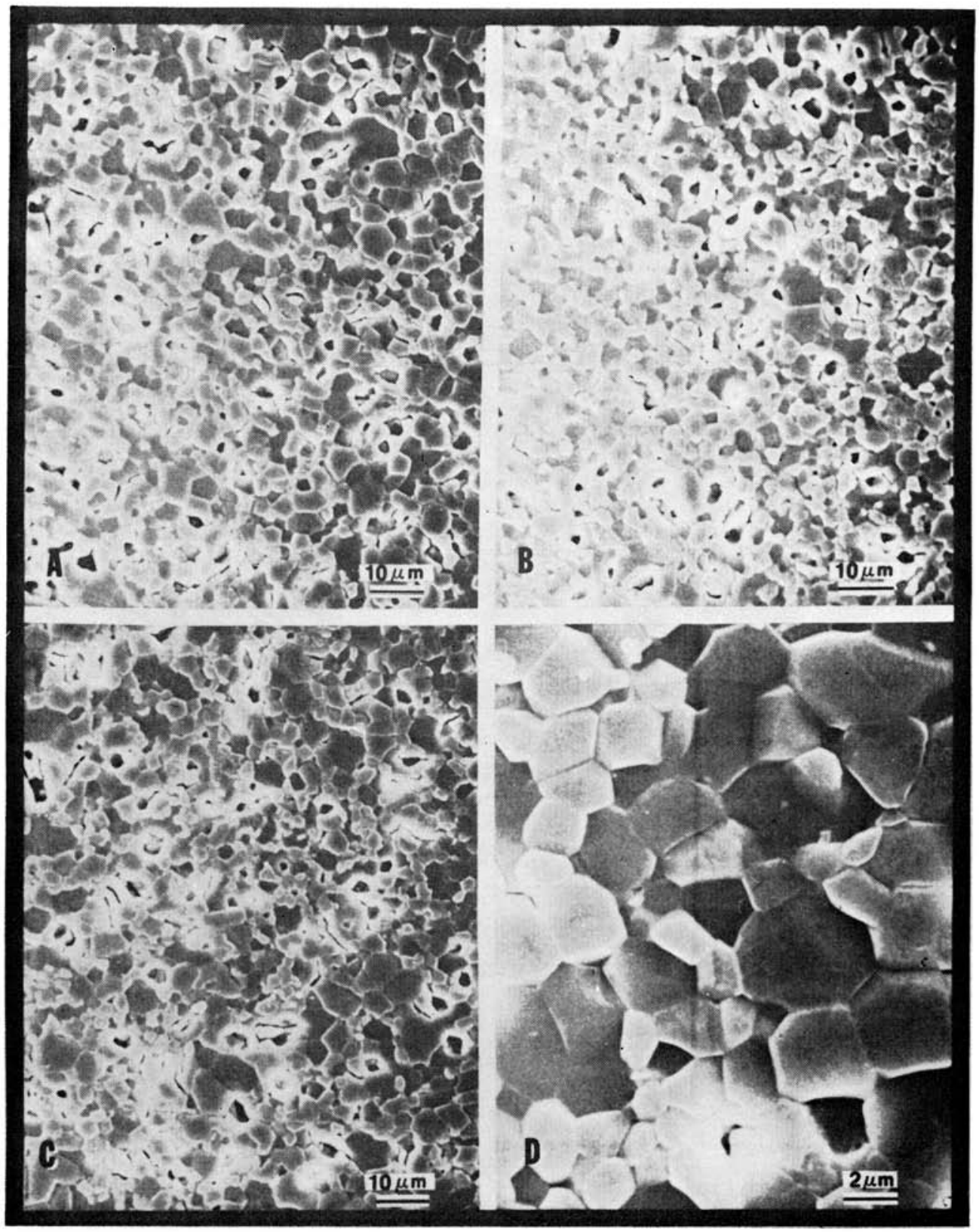

Fig 2.-SEM photomicrographs of sintered and etched HAP surfaces compacted at 138
(A), 276 (B), and 414 (C) MPa. A higher magnification of $\mathrm{C}$ is shown in $\mathrm{D}$. 
TABLE

Properties of a Sintered Hydroxyapatite Ceramic (HAP-60K-1200 C) Compared with HuMan ENamei

\begin{tabular}{lcc}
\hline & HAP-60K-1200C & Enamel \\
\hline $\begin{array}{l}\text { Compressive Strength } \\
\mathrm{MN} / \mathrm{m}^{2}\end{array}$ & $376(13)^{*}$ & $400^{14}$ \\
$\begin{array}{l}\text { Young's Modulus } \\
\left(\mathrm{GN} / \mathrm{m}^{2}\right)\end{array}$ & $121(6)$ & $77.9^{15}$ \\
$\begin{array}{l}\text { Knoop Hardness } \\
\left(\mathrm{Kg} / \mathrm{mm}^{2}\right)\end{array}$ & $450(13)$ & $343^{16}$ \\
$\begin{array}{l}\text { Density } \\
\left(\mathrm{gm} / \mathrm{cm}^{3}\right.\end{array}$ & 3.1 & $2.96^{16}$ \\
$\begin{array}{l}\text { Coefficient of Friction } \\
\text { Linear Coefficient of } \\
\quad \text { Thermal Expansion } \\
\left(10^{-6} / \mathrm{C}\right)\end{array}$ & 0.239 & $0.36^{11}$ \\
& $9.2-11.8$ & $11.4^{16}$ \\
\hline
\end{tabular}

* Mean of 5 replications with standard deviation in parentheses.

less than $3 \mathrm{~N}$ gave excessively high values because of elastic recovery of the indentation; thus, all microhardness values for the HAP ceramic were obtained with a $4 \mathrm{~N}$ load. Hardness was observed to be dependent on compaction pressure (Fig. 3). Knoop hardness numbers increased from 400 for $138 \mathrm{MPa}$ specimens to 450 for $414 \mathrm{MPa}$ specimens. Some of this increase in hardness was caused by a decrease in closed porosity with increasing compaction pressure.

The linear coefficient of thermal expansion of the sintered compacts decreased with

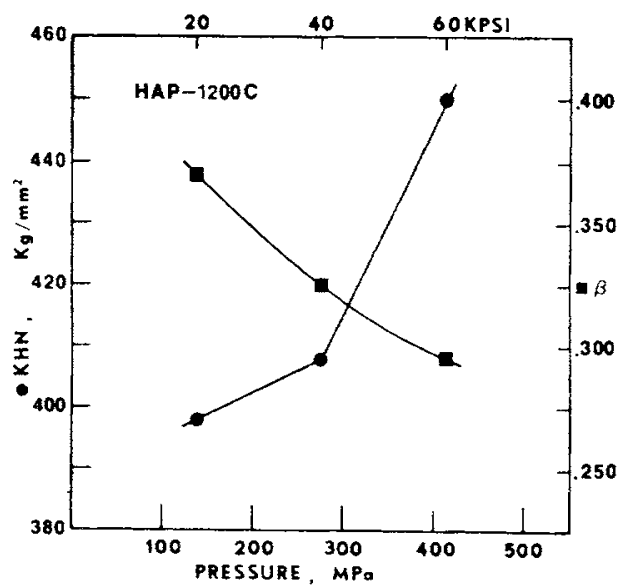

FIG 3.--Knoop hardness and coefficient of friction $(\beta)$ as a function of compaction pressure for the sintered HAP-1200C specimens.

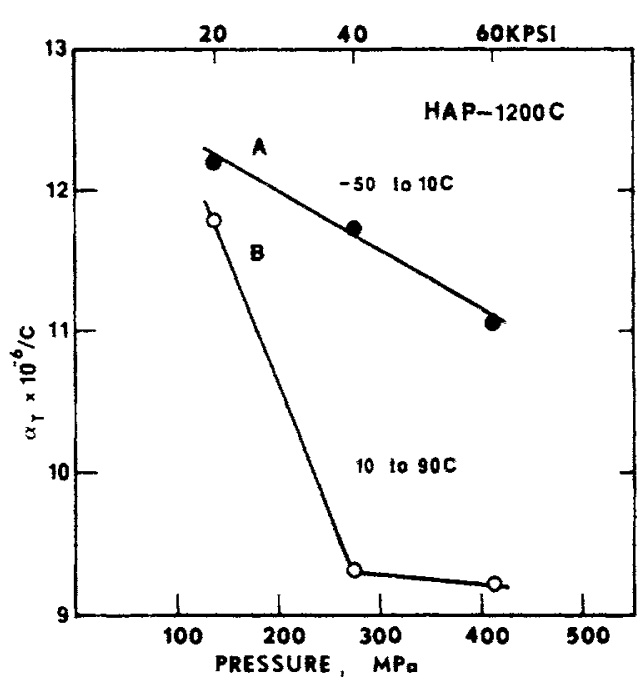

FIG 4.-Thermal coefficients of expansion of sintered HAP- $1200 \mathrm{C}$ specimens as a function of compaction pressure showing temperature dependence.

increasing compaction pressure as shown in Figure 4. Two different slopes were observed in the thermal expansion curves between -50 and $90 \mathrm{C}$. The values from the first curve are plotted as a line $\mathrm{A}$ for -50 to $10 \mathrm{C}$ range. The second curve from 10 to $90 \mathrm{C}$ is given as line $\mathrm{B}$. Both temperature ranges showed a decrease in the coefficient of expansion with increasing compaction pressure; however, the largest decrease was observed in the 10 to $90 \mathrm{C}$ range

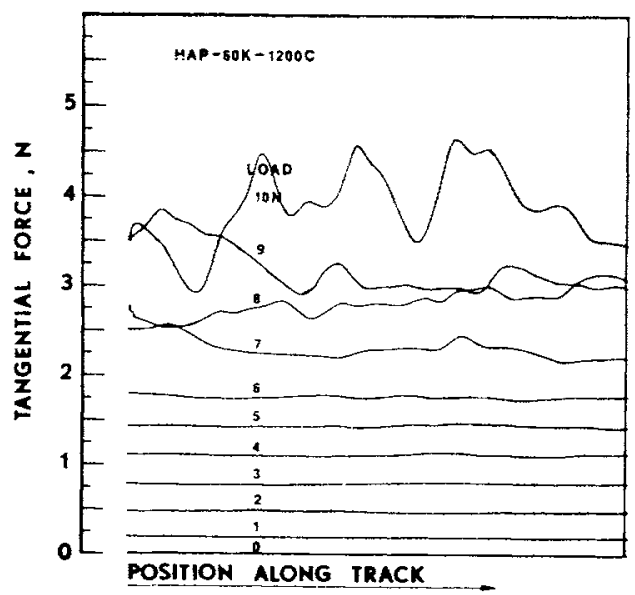

Fig 5.-Tangential force of the wear tracks of a HAP-60K-1200C specimen as a function of load. 


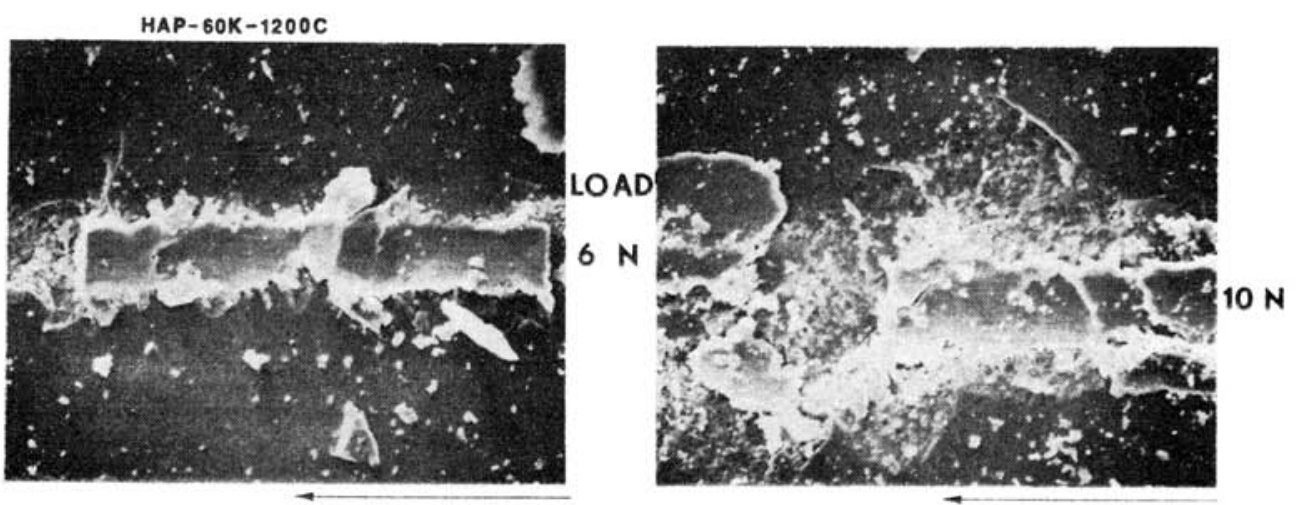

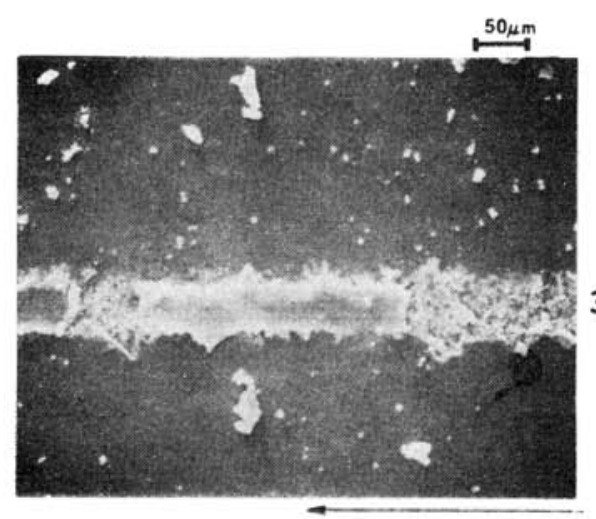

Fig 6.-SEM photomicrographs of four selected wear tracks of HAP-60K-1200C. The arrows indicate the direction of sliding. The

from 12 to $9 \times 10^{-6} / \mathrm{C}$ for the compacts made at 138 and $414 \mathrm{MPa}$, respectively.

Wear of HAP-60K-1200C specimens was determined by making 10 parallel, single-pass scratches on 5 specimens by sliding in distilled water under normal loads of 1 to $10 \mathrm{~N}$ in increments of $1 \mathrm{~N}$. Tangential force data were plotted on an $\mathrm{x}-\mathrm{y}$ recorder. A sample recording for a HAP-60K-1200C specimen (Fig 5) showed a definite change in the frictional behavior above a $6 \mathrm{~N}$ load that indicated a change in a mode of surface failure. The first 6 wear tracks (1 to $6 \mathrm{~N}$ ) were relatively smooth and showed very little tensile cracking or chevrons (Fig 6, left). In contrast, the tracks from 7 to $10 \mathrm{~N}$ load showed considerable surface failure as indicated by tensile, cracking and chevron formation of the surface adjacent to the wear track (Fig 6, right).

Mean values of track width and tangential force data for the HAP-60K-1200C specimens

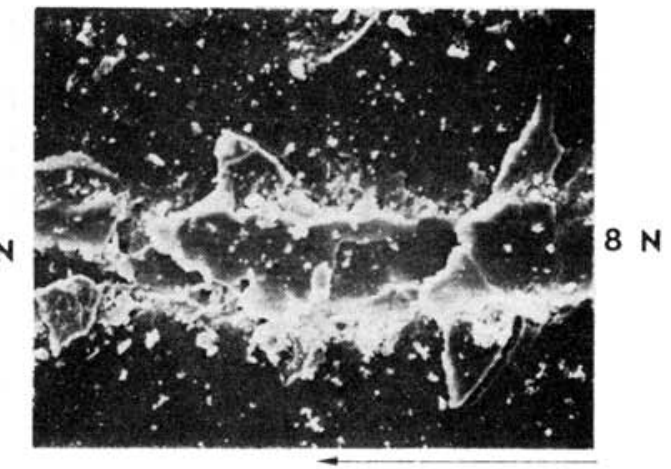

normal load is indicated at the right of each photomicrograph.

are plotted in Figure 7 as solid points. Both curves showed a discontinuity at a load above $6 \mathrm{~N}$ indicating a change in the mode of surface failure from ductile to brittle. Correspondingly, values of the coefficient of friction changed from 0.3 at lower loads to 0.5 at loads above $6 \mathrm{~N}$. The data for enamel ${ }^{11}$ (open points) are shown for comparison. The effect of compaction pressure on the coefficient of friction at loads helow $6 \mathrm{~N}$ is shown in Figure 3.

\section{Discussion}

The HAP ceramic compacted at $138 \mathrm{MPa}$ and sintered at $1200 \mathrm{C}$ for 12 hours had values of hardness and coefficient of friction that were closer to those values of enamel than HAP$60 \mathrm{~K}-1200 \mathrm{C}$ (see Fig 3); however, the former ceramic had more extensive surface porosity than HAP-60K-1200C that resulted in a brittle mode of surface failure below loads of $6 \mathrm{~N}$. Further research should be directed toward 


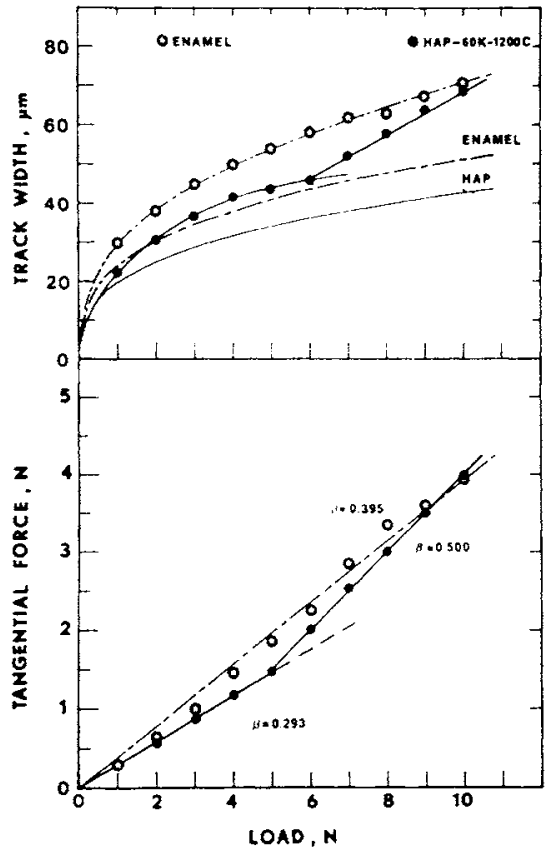

Fig 7.-Track width and tangential force data versus normal load for both human enamel 11 and the HAP-60K-1200C ceramic. The dashed and solid lines without data points were calculated from Hertz's model.

reducing the brittleness and hardness of the HAP ceramic while minimizing the amount of surface porosity.

Track width data for enamel (Fig 7) are higher than those for the HAP ceramic because of the lower hardness of human enamel. Theoretical track width data were computed for both human enamel and the HAP ceramic on the basis of Hertz's equation of elasticity. ${ }^{12,13}$ Young's modulus used in calculations for enamel $^{1 \pm}$ was $77.9 \mathrm{GN} / \mathrm{m}^{2}$ and for $\mathrm{HAP}^{1.5}$ was $121 \mathrm{GN} / \mathrm{m}^{2}$. Enamel is represented by a broken line and the HAP ceramic by a solid line in Figure 7 . Both curves fall relatively close to the measured data, although the measured data are higher than predicted by the model of two elastic bodies. The higher values of the measured data compared to the data calculated from Hertz's model may be caused by the ductility of the enamel and the brittleness of the HAP cramic, respectively, which are not taken into account in Hertz's model.

The relatively close agreement among the physical properties (Table) of the HAP ceramic and human enamel suggests that the HAP ceramic may be a suitable model for friction and wear studies of human enamel. Wear of the HAP ceramic as characterized by single-pass sliding approximates that of human ename ${ }^{11}$ reasonably well.

\section{Conclusions}

A hydroxyapatite (HAP) ceramic for use as a model for wear studies of human enamel was made by isostatic compaction of a commercial grade of tricalcium phosphate at pressures up to $414 \mathrm{MPa}(60,000 \mathrm{psi})$ and sintering at $1200 \mathrm{C}$ for 12 hours in an atmosphere of one part nitrogen and one part steam. Physical properties of this ceramic compared favorably with those of human enamel. Frictional behavior and wear of the HAP ceramic were evaluated under single-pass sliding in water. A change in the mode of surface failure from ductile at lower loads to brittle at loads above 6 $\mathrm{N}$ was observed. The measured track widths and the coefficient of friction of the HAP ceramic were comparable to those of human enamel.

\section{References}

1. Nery, E.B.; Lynah, K.L.; Hirthe, W.M.; and MUeller, K.H.: Bioceramic Implants in Surgically Produced Infrabony Defects, $J$ Periodontol 46:328-347, 1975.

2. Levitt, S.R.; Crayton, P.H.; Monroe, E.A.; and Condrate, R.A.: Forming Methods for Apatite Prosthesis, J Biomed Mater Res 3:683-684, 1969.

3. Monroe, E.A.; Votava, Ward; Bass, D.B.; and MaMullen, James: New Calcium Phosphate Ceramic Material for Bone and Tooth Implants, $J$ Dent Res 50:860-861, 1971.

4. RAO, W.R., and Boemm, R.F.: A Study of Sintered Apatites, $J$ Dent Res 53:13511354, 1974.

5. Jarcho, Michael; Bolen, G.H.; Thomas, M.B.; Bobick, J. ; KAY, J.F.; and Doremus, R.H.: Hydroxylapatite Synthesis and Characterization in Dense Polycrystalline Form, J Mater Sci $11: 2027-2035,1976$.

6. JARcho, Michael; O'Connor, J.R.; and PARIS, D.A.: Ceramic Hydroxylapatite as a Plaque Growth and Drug Screening Substrate, J Dent Res 56:151-156, 1977.

7. Hubbard, William: Physiological Calcium Phosphate as Orthopedic Implant Material. $\mathrm{PhD}$ thesis, Marquette University, 1974.

8. Rootare, H.M., and Craig, R.G.: Characterization of Hydroxyapatite Powders and 
Compacts at Room Temperature and After Sintering at $1200 \mathrm{C}, J$ Oral Rehabil (In Press).

9. Rootare, H.M. and Craig, R.G.: Characterization of the Compaction and Sintering of Hydroxyapatite Powders by Mercury Porosimetry, Powder Technology 9:199$211,1974$.

10. LEHr, J.R.; Brown, E.T.; Frazier, A.W.; SMITH, J.P.; and Thrasher, R.D.: Crystallographic Properties of Fertilizer Compounds, Tennessee Valley Authority Chemcal Engineering Bulletin No. 6, Muscle Shoals, Alabama, May 1967.

11. Powers, J.M.; Craig, R.G.; and Ludema, K.C.: Frictional Behavior and Surface Failure of Human Enamel, J Dent Res 52:13271331, 1973.
12. Hertz, H.R.: On the Contact of Elastic Solids, I Reine Angew Math 92:156-171, 1881.

13. Powers, J.M.; Ludema, K.C.; and Craig, R.G.: Wear of Fluorapatite Single Crystals: IV. Influence of Sliding Direction on Frictional Behavior and Surface Failure, $J$ Dent Res 52:1019-1025, 1973.

14. Craig, R.G.; Peyton, F.A.; and Johnson, D.W.: Compressive Properties of Enamel, Dental Cements, and Gold, J Dent Res 40: 936-945, 1961.

15. Grenoble, D.E.; Katz, J.L.; Dunn, K.L.; Gilmore, R.S.; and Murty, K.L.: The Elastic Properties of Hard Tissues and Apatites, J Biomed Mater Res 6:221-233, 1972.

16. Craig, R.G.; and Peyton, F.A.: Restorative Dental Materials, 5th ed. St. Louis, Mosby, 1975. 